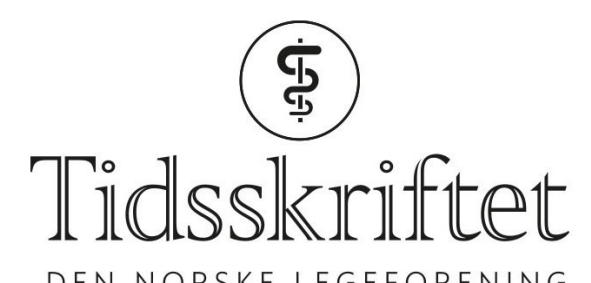

DEN NORSKE LEGEFORENING

\title{
Glioblastomers vekstdynamikk
}

DOKTORAVHANDLINGER

ANNE LINE STENSJØEN

E-post:alinesten@gmail.com

Veksthastigheten til glioblastomer før behandling ser ut til å være assosiert med overlevelse.

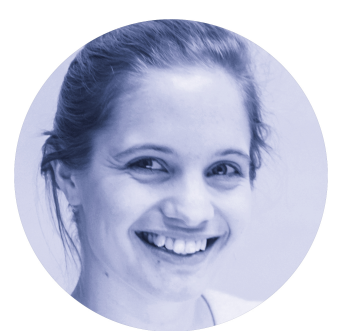

Foto: Bjørnar Brende Smestad

Glioblastomer er aggressive, diffust voksende hjernesvulster med dårlig prognose. Etablerte prognostiske faktorer er alder, funksjonsnivå, størrelse av restsvulst etter operasjon samt isositratdehydrogenasemutasjonsstatus. Glioblastomenes vekstdynamikk er lite studert in vivo, og det har vært ukjent om veksthastigheten har prognostisk betydning.

I min avhandling har vi studert veksthastigheten til glioblastomer før behandling for å se om den kunne være en prognostisk markør eller var assosiert med histopatologiske trekk. I tre utforskende studier målte vi volumendringer av glioblastomer fra 106 pasienter som hadde hatt to MR-undersøkelser før behandling. I tillegg studerte vi histopatologiske trekk i svulstene og samlet inn data om behandling og overlevelse.

Vi fant store forskjeller i glioblastomenes veksthastighet i tiden før behandling. Median doblingstid var 50 dager, og nesten en tredel av svulstene doblet volumet i tiden før operasjonen. Dette understøtter $ø$ nsket om tidlig behandling, som i dag sikres med pakkeforløp. Pasienter med saktevoksende svulster hadde fire ganger høyere odds for å leve lenger enn to år. Høy celletetthet og/eller tromboser i vevsprøver var assosiert med hurtigvoksende svulster.

Hvis funnene bekreftes i hypotesetestende studier, kan dette bedre vår evne til å prognostisere og øke den biologiske forståelsen av tilstanden. Veksthastighet kan også representere et endepunkt i jakten på molekylærbiologiske faktorer av klinisk betydning. 


\section{Disputas}

Anne Line Stensjøen disputerte for ph.d.-graden ved Norges teknisk-naturvitenskapelige universitet 15.2.2017. Tittelen på avhandlingen er Pretreatment growth dynamics of glioblastomas - volumetric assessment with histopathological associations and prognostic implications.

Publisert: 18. september 2017. Tidsskr Nor Legeforen. DOI: 10.4045/tidsskr.17.0499

(C) Tidsskrift for Den norske legeforening 2020. Lastet ned fra tidsskriftet.no 